\title{
HUBUNGAN PENGETAHUAN LINGKUNGAN HIDUP DENGAN KESADARAN LINGKUNGAN PADA SISWA SEKOLAH ADIWIYATA
}

\author{
Syella Munawar ${ }^{1}$, Erna Heryanti ${ }^{2}$, Mieke Miarsyah ${ }^{3}$ \\ Program Studi Pendidikan Biologi, Fakultas Matematika dan Ilmu Pengetahuan Alam, \\ Universitas Negeri Jakarta ${ }^{123}$ \\ syella.mun16@gmail.com ${ }^{1}$, erna.heryanti@gmail.com ${ }^{2}$, mmiarsyah@unj.ac.id ${ }^{3}$
}

\begin{abstract}
ABSTRAK
Jakarta merupakan wilayah perkotaan di Indonesia yang memiliki banyak permasalahan lingkungan. Kesadaran lingkungan diperlukan dalam upaya untuk menyelesaikan permasalahan lingkungan. Kesadaran lingkungan dalam diri siswa dapat dibentuk oleh tingkat pengetahuan lingkungan. Program sekolah berbasis lingkungan dilaksanakan melalui program Adiwiyata. Tujuan program Adiwiyata untuk mendorong dan menciptakan sekolah yang peduli tentang lingkungan dan memiliki budaya lingkungan. Penelitian ini bertujuan untuk mengetahui hubungan pengetahuan lingkungan hidup dengan kesadaran lingkungan pada siswa sekolah Adiwiyata. Penelitian ini dilaksanakan di SMAN 26 dan SMAN 65 Jakarta pada Semester I Tahun Ajaran 2018/2019. Metode yang digunakan yaitu metode deskriptif kuantitatif melalui studi korelasional. Sampel yang digunakan sebanyak 124 siswa menggunakan teknik Simple Random Sampling. Alat pengumpulan data menggunakan tes pengetahuan lingkungan hidup dan instrumen kesadaran lingkungan. Analisis uji prasyarat menunjukkan data berdistribusi normal menggunakan uji KolmogorovSmirnov dan homogen menggunakan uji Bartlett. Hasil penelitian menunjukkan bahwa terdapat hubungan positif dan signifikan antara pengetahuan lingkungan hidup dengan kesadaran lingkungan siswa dengan koefisien korelasi sebesar 0,298. Hal tersebut berarti jika skor pengetahuan lingkungan hidup tinggi, maka skor kesadaran lingkungan juga tinggi. Pengetahuan lingkungan hidup memberikan kontribusi terhadap kesadaran lingkungan siswa sebesar $8,89 \%$.
\end{abstract}

Kata kunci : Adiwiyata, kesadaran, lingkungan hidup, pengetahuan.

\section{PENDAHULUAN}

Jakarta merupakan wilayah perkotaan di Indonesia dengan angka kepadatan penduduk mencapai $15.366,85$ jiwa/km². Nilai Indeks Kualitas Lingkungan Hidup (IKLH) Jakarta tahun 2016 berada pada posisi paling bawah dari 33 provinsi lain yaitu 38,69 (KLHK, 2017). Permasalahan lingkungan terbanyak di Jakarta diantaranya polusi udara dan timbunan sampah. Badan Pusat Statistik mencatat rata-rata konsentrasi partikel terlarut di udara bulan November tahun 2016 dari stasiun pengamatan Glodok (Jakarta) memasuki level tidak sehat (unhealthy) yaitu $340,23 \mu \mathrm{g} / \mathrm{m}^{3}$. Perkiraan produksi sampah di Jakarta tahun 2016 sebanyak 7099,08 $\mathrm{m}^{3}$ per hari (BPS, 2017). Pengetahuan yang kurang dalam pengelolahan sampah merupakan salah satu penyebab meningkatnya tumpukan sampah (Rahmahdini, 2014).

Upaya pelestarian lingkungan merupakan tugas seluruh masyarakat yang berinteraksi dengan lingkungannya termasuk siswa. Mengembangkan kesadaran dan sikap positif terhadap lingkungan perlu ditanamkan sejak usia remaja. Hal ini dikarenakan usia remaja sangat sensitif terhadap masalah lingkungan (Kukreti dan Gihar, 2004). Kesadaran lingkungan mendorong siswa 
lebih mempertimbangkan implikasi suatu perilaku terhadap lingkungannya (Darsita et al., 2015). Kesadaran lingkungan merupakan keadaan tergugahnya jiwa atau mengetahui sesuatu secara mendalam terkait lingkungan hidup dan dapat tercermin melalui perilaku dan tindakan setiap individu (Neolaka, 2008). Kesadaran lingkungan yang tinggi kemungkinan besar akan mendorong seseorang berperilaku positif yang mendukung kelestarian lingkungan hidup (Wihardjo et al., 2017).

Menciptakan kesadaran lingkungan perlu adanya pengetahuan sebelumnya tentang lingkungan yang diperoleh baik secara mandiri maupun dari proses belajar di kelas. Pengetahuan adalah hasil penginderaan manusia atau hasil tahu seseorang terhadap objek melalui indra yang dimilikinya (Notoatmodjo, 2007). Pengetahuan tentang pencemaran dapat berpengaruh terhadap berpikir kritis sehingga siswa lebih terdorong menyelesaikan permasalahan lingkungan (Izzaty, 2014). Adanya pengetahuan yang diperoleh dapat menjadikan siswa berwawasan lingkungan hidup, sehingga tercipta pemecahan masalah solutif (Vivanti et al., 2017)

Kesadaran lingkungan menurut Environmental Awareness Ability Measure (EAAM) yang dikembangkan oleh Jha (1998) dalam Shobeiri et al. (2007) terdiri atas 5 dimensi, yaitu dimensi penyebab polusi (causes of pollution), dimensi konservasi tanah, udara, air, dan hutan (conservation of soil, air, water, forest), dimensi konservasi energi (energy conservation), dimensi konservasi kesehatan manusia (conservation of human health), dimensi konservasi kehidupan alam liar dan peternakan (conservation of wild life and animal husbandry). Kesadaran lingkungan dipengaruhi oleh faktor ketidaktahuan, kemiskinan, kemanusiaan, dan gaya hidup (Neolaka, 2008).

Kementerian Lingkungan Hidup bekerja sama dengan Kementerian
Pendidikan dan Kebudayaan mencetuskan program Adiwiyata sejak tahun 2006 sebagai implementasi pendidikan lingkungan hidup. Program ini bertujuan mendorong dan membentuk sekolah peduli dan berbudaya lingkungan yang mampu berpartisipasi, melaksanakan upaya pelestarian lingkungan dalam pembangunan berkelanjutan (KLH, 2012).

Keberhasilan program Adiwiyata didukung dengan keterlibatan siswa secara aktif. Keterlibatan siswa dalam pelaksanaan Adiwiyata dengan mengikuti semua aturan, seperti bebas dari asap rokok, membuang sampah sesuai dengan jenisnya organik atau anorganik, menjaga kebersihan lingkungan sekolah, melakukan penghijuan, membawa botol air sendiri dan wadah makanan untuk mengurangi sampah plastik (Bowosantoso, 2015). Siswa juga berperan dalam menghemat penggunaan air, energi, menerapkan prinsip 5R (Reduce, Reuse, Recycle, Replace, Replant). Program Adiwiyata menerapkan unit kebijakan Bank Sampah yang dikelola secara mandiri oleh siswa. Aktivitas lain yang dilakukan siswa seperti mengikuti ekstrakurikuler atau komunitas yang bertemakan lingkungan, (Maryono, 2015).

SMA di Jakarta yang menerapkan program Adiwiyata adalah SMA Negeri 26 dan SMA Negeri 65. Berdasarkan hasil observasi, sekolah sudah menyediakan sarana dan prasarana pendukung yang ramah lingkungan. Namun pada kenyataannya masih ditemukan siswa yang belum mampu menjaga kebersihan lingkungan sekolah dengan baik.

Berdasarkan pemaparan latar belakang masalah, maka diperlukan penelitian untuk melihat hubungan antara pengetahuan lingkungan hidup dengan kesadaran lingkungan pada siswa sekolah Adiwiyata. 


\section{METODE}

Metode penelitian yang digunakan adalah metode deskriptif kuantitatif melalui studi korelasional. Variabel bebas dalam penelitian ini adalah pengetahuan lingkungan hidup pada siswa sekolah Adiwiyata sedangkan variabel terikat adalah kesadaran lingkungan pada siswa sekolah Adiwiyata.

\section{Metode Pengumpulan Data}

Metode pengumpulan data dilakukan melalui pengisian tes pengetahuan lingkungan hidup dan instrumen kesadaran lingkungan yang ditujukan kepada responden. Penelitian dilaksanakan di SMA Negeri 26 Jakarta dan SMA Negeri 65 Jakarta pada bulan Oktober 2018. Sampel pada penelitian ini sebanyak 124 siswa yang dipilih secara simple random sampling dari total dari 180 siswa yang berasal dari tiga kelas rombongan belajar SMA Negeri 26 Jakarta dan dua kelas rombongan belajar SMA Negeri 65 Jakarta. Jumlah sampel ditentukan menggunakan rumus Slovin.

\section{Metode Analisis Data}

Teknik analisis data yang digunakan meliputi :

1. Uji prasyarat analisis datadengan melakukan uji normalitas Kolmogorov Smirnov dan uji homogenitas Bartlett.

2. Uji hipotesis menggunakan persamaan regresilinier dan korelasi sederhana.

Hipotesis yang terdapat pada penelitianini yaitu :

$\mathrm{H}_{0}: \rho x y=0$

$\mathrm{H}_{1}: \rho x y>0$

$\mathrm{H}_{0}$ : Tidak terdapat hubungan positif antara pengetahuan lingkungan hidup dengan kesadaran lingkungan pada siswa sekolah Adiwiyata.

$\mathrm{H}_{1} \quad$ : Terdapat hubungan positif antara pengetahuan lingkungan hidup dengan kesadaran lingkungan pada siswa sekolah Adiwiyata.

\section{HASIL}

a) Pengetahuan Lingkungan Hidup

Berdasarkan hasil penelitian yangdiperoleh, nilai tertinggi pengetahuan lingkungan hidu yaitu 97 dan terendah yaitu 56. Nilai-nilai diinterpretasikan kedalam 3 kategori yaitu rendah, sedang, dan tinggi. Kategori interpretasi nilai yang paling dominan yaitu kategori sedang seperti pada Gambar 1.

Gambar 1. Kriteria Interpretasi Nilai Pengetahuan Lingkungan Hidup

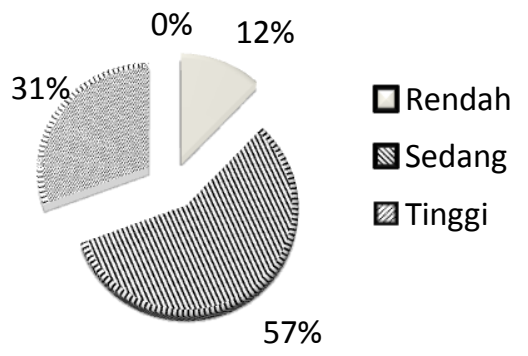

b) Kesadaran Lingkungan

Berdasarkan hasil penelitian yang diperoleh, nilai tertinggi kesadaran lingkungan pada siswa sekolah Adiwiyata yaitu 96 dan terendah yaitu 67. Nilai-nilai tersebut diinterpretasikan kedalam 3 kategori yaitu rendah, sedang, dan tinggi. Kategori interpretasi nilai yang mendominasi yaitu kategori sedang seperti pada Gambar 2.

Gambar 2. Kriteria Interpretasi Nilai Kesadaran Lingkungan pada Siswa Adiwiyata.

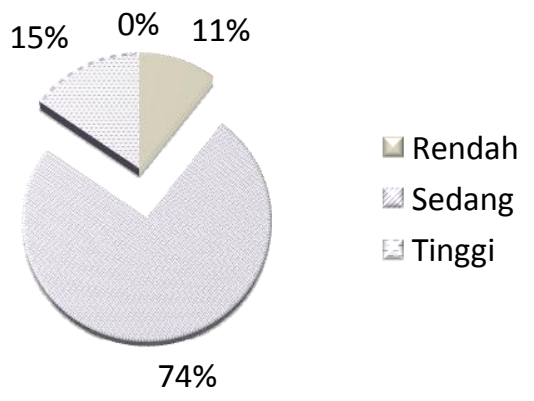


Responden pada penelitian memiliki karakteristik yang dilihat berdasarkan jenis kelamin. Berdasarkan hasil penelitian yang diperoleh, nilai rata-rata siswa berjenis kelamin perempuan lebih baik dibandingkan laki-laki yaitu 83,17 seperti pada Gambar 3.

Gambar 3. Perbandingan Nilai Rata-

Rata Kesadaran Lingkungan Siswa Berdasarkan Gender

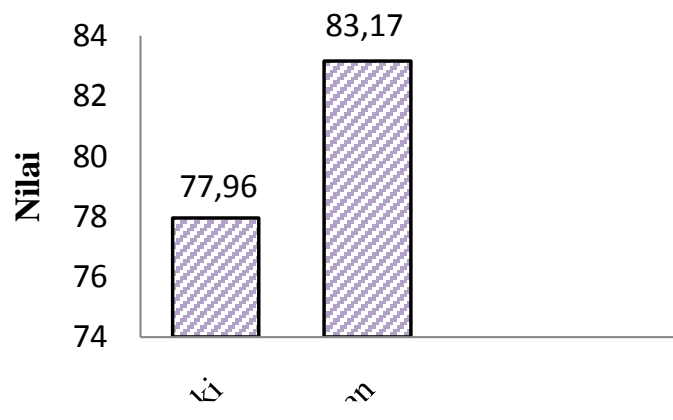

Hasil uji model regresi linier sederhana didapatkan bahwa model regresisignifikan dengan menghasilkan model persamaan $\hat{Y}=64,355+0,195 X$. Persamaan regresi tersebut menunjukkan bahwa setiap kenaikan variabel pengetahuan lingkungan hidup sebesar satu nilai dapat menyebabkan kenaikan kesadaran lingkungan sebesar 0,195 nilai pada konstanta 64,355.

Berdasarkan hasil perhitungan, kekuatan hubungan sebesar 0,298 yang berarti tingkat kekuatan hubungan rendah dan hasil dari koefisien determinasi $\left(\mathrm{r}^{2} \mathrm{xy}\right)$ sebesar 0,089 seperti pada Tabel 1 .

Tabel 1. Nilai Koefisien Korelasi dan Determinasi antar Variabel.

\begin{tabular}{|c|c|c|c|c|}
\hline \multicolumn{5}{|c|}{ Model Summary $^{\mathrm{b}}$} \\
\hline \multirow{3}{*}{$\begin{array}{l}\text { Model } \\
1\end{array}$} & \multirow{3}{*}{$\begin{array}{l}\mathrm{R} \\
, 298^{\mathrm{a}}\end{array}$} & \multirow{3}{*}{$\begin{array}{l}\text { R Square } \\
\text {,089 }\end{array}$} & \multirow{2}{*}{$\begin{array}{l}\text { Adjusted R } \\
\text { Square }\end{array}$} & \multirow{2}{*}{$\begin{array}{l}\text { Std. Error of the } \\
\text { Estimate }\end{array}$} \\
\hline & & & & \\
\hline & & & ,081 & 5,288 \\
\hline a. $\operatorname{Pr}$ & & nt), Pen & ahuan Li & ungan Hidup \\
\hline b. De & & ค. Kacs & an linokur & \\
\hline
\end{tabular}

\section{PEMBAHASAN}

Gambar 1 menunjukkan bahwa lebih dari separuh jumlah siswa memiliki pengetahuan lingkungan yang tergolong sedang. Berdasarkan hasil penelitian Spínola (2015) menyatakan bahwa pengetahuan lingkungan antara siswa EcoSchool (sekolah berwawasan lingkungan) sedikit lebih tinggi daripada siswa Non Eco-School atau sekolah umum. Jika dikaitkan dengan hasil tersebut, maka terdapat kontribusi program Adiwiyata dalam meningkatkan pengetahuan lingkungan sehingga hanya sedikit siswa yang memiliki nilai pengetahuan lingkungan kategori rendah.Notoatmodjo (2007) mengemukakan bahwa pengetahuan seseorang diperoleh melalui proses penginderaan terhadap suatu objek tertentu.

Pengetahuan lingkungan yang rendah menyebabkan siswa kekurangan informasi yang menjadi dasar untuk berperilaku tidak merusak lingkungan. Bersesuaian dengan pernyataan Pe'er et al. (2007) rendahnya tingkat pengetahuan lingkungan menjadi faktor yang mempengaruhi seseorang untuk mengabaikan implikasi dari perilaku sehari-hari pada lingkungannya. Berdasarkan pernyataan tersebut, dapat juga dikatakan siswa yang memiliki tingkat pengetahuan lingkungan kategori sedang cenderung lebih memperhatikan dan berempati pada konsekuensi perilaku mereka terhadap lingkungan.

Siswa yang memiliki pengetahuan lingkungan tinggi akan semakin sadar untuk melestarikan lingkungannya. Sesuai pernyataan Creech et al. (2009), bahwa pengetahuan lingkungan yang tinggi dapat meningkatkan kesadaran lingkungan, yang mengarah pada perubahan perilaku seseorang.

Pengetahuan lingkungan diperoleh siswa baik secara mandiri maupun dari proses belajar di kelas salah satunya pada mata pelajaran biologi. Selain itu, pengetahuan dapat diserap melalui media internet. Siswa dapat melihat berita 
pemanasan global, menurunnya keanekaragaman hayati, dan ancaman lingkungan lainnya berasal dari media. Sesuai dengan penjelasan Rahman (2016) bahwa media cetak, elektronik, dan internet adalah sumber dari informasi yang akan mempengaruhi tingkat pengetahuan seseorang. Selain itu, siswa juga mendapatkan pengetahuan lingkungan melalui pengamatan langsung terhadap fenomena lingkungan di Jakarta, seperti tumpukan sampah, polusi udara, pencemaran air sungai, dan banjir. Sesuai penjelasan Piaget dalam Siregar dan Hartini (2010) yang mengemukakan bahwa pengetahuan merupakan ciptaan manusia yang dikonstruksikan melalui pengalaman, proses pembentukan berjalan terus menerus dan setiap kali terjadi rekonstruksi oleh pemahaman baru.

Gambar 2 menunjukkan bahwa nilai kesadaran lingkungan siswa terbanyak berada dalam kategori sedang. Artinya, sebagian siswa sudah memiliki kesadaran untuk bertindak konkret melestarikan lingkungan. Menurut Azrai, Sigit, dan Puji (2017) kesadaran siswa terhadap lingkungan dapat membentuk sikap dan perilaku lingkungan yang bertanggung jawab dalam menjaga dan melestarikan lingkungan sekolah. Kesadaran lingkungan dapat ditanamkan dalam diri siswa melalui kegiatan ekstrakurikuler bertemakan lingkungan seperti pramuka, adanya pelatihan dan perkemahan memberikan pengalaman langsung sehingga membentuk sikap peduli terhadap lingkungan (Heryanti, 2016). Selain itu, belum banyak siswa yang memperoleh nilai kesadaran lingkungan kategori tinggi meskipun sekolah sudah menerapkan program Adiwiyata, hal ini dapat disebabkan karena belum ada sanksi tegas bagi siswa yang melanggar aturan program tersebut. Bersesuaian dengan pendapat Coyle (2004) yang menjelaskan bahwa program lingkungan akan lebih efektif ketika sekolah membuat sistem yang stimulan dan insentif, diberikan apresiasi (reward) dan hukuman (punishment) agar siswa mematuhi program yang diterapkan. Faktor yang mempengaruhi kesadaran lingkungan juga didukung data karakterisasi berdasarkan gender seperti pada Gambar 3. Dapat diketahui siswa perempuan memiliki rata-rata nilai kesadaran lingkungan lebih tinggi dibandingkan laki-laki. Perempuan cenderung menampilkan tingkat komitmen dan tanggung jawab yang lebih tinggi daripada laki-laki pada aspek tindakan karena lebih sensitif terhadap lingkungan. Sesuai dengan pendapat Omoogun dan Odok (2013), bahwa terdapat perbedaan persepsi berdasarkan gender terhadap lingkungan terkait pemanfaatan hutan, degradasi dan konservasi lingkungan. Perbedaan persepsi ini akan diwariskan dari satu generasi lain melalui sosialisasi peran gender. Laki-laki dianggap lebih terlibat dalam kegiatan merusak lingkungan seperti kegiatan penebangan hutan dibandingkan perempuan.

Berdasarkan hasil uji korelasi (Tabel 1), dinyatakan terdapat korelasi yang rendah sebesar 0,298. Hal ini dikarenakan terbentuknya kesadaran lingkungan dalam diri siswa tidak sepenuhnya dipengaruhi faktor pengetahuan lingkungan saja. Sejalan dengan penelitian Ziadat (2010) terkait evaluasi faktor utama yang berkontribusi terhadap kesadaran lingkungan pada masyarakat Yordania. Hasil penelitian menunjukkan faktor sosiodemografi (tingkat pendidikan, usia, jenis kelamin, dan area tempat tinggal) mempengaruhi kesadaran lingkungan.

Pendidikan membantu seseorang untuk menjadi rasional, sadar dan menjadi akrab dengan informasi yang mendukung kesadaran lingkungan. Semakin tingggi tingkat pendidikan, seseorang lebih sadar tentang aspek lingkungan. Kesadaran lingkungan juga dipengaruhi oleh perbedaan rentang usia. Seseorang yang memiliki usia yang lebih tua, kemungkinan memiliki kesadaran lingkungan lebih baik. Faktor perbedaan jenis kelamin dapat berpengaruh terhadap kesadaran lingkungan dikarenakan 
perempuan memiliki lebih banyak tanggung jawab atas manajemen harian yang berkaitan dengan pengunaan air, bahan kimia rumah tangga, dan pembuangan limbah padat. Tempat tinggal responden dapat menentukan tingkat kesadaran lingkungan. Perkotaan sebagai zona ekonomi memiliki keragaman pengunjung dari seluruh daerah. Seseorang yang tinggal dikota memiliki paparan pandangan yang luas. Selain itu diperkotaan mendapatkan fasilitas lebih, seperti standar hidup tinggi, kesempatan pendidikan, penggunaan teknologi modern, pameran, seminar, dan festival. (Ziadat, 2010; Sarker et al., 2018).

Pendapat lain mengemukakan pengetahuan dalam mempengaruhi kesadaran tidak bersifat langsung. Salah satu yang dapat memediasi antara pengetahuan dan kesadaran adalah persepsi. Hal tersebut didukung oleh penyataan Krech (2000) bahwa persepsi tergantung dari pengetahuan dan pengalaman yang dimiliki, kemudian mengakibatkan seseorang memiliki kesadaran untuk melakukan suatu perilaku. Persepsi merupakan proses pengorganisasian, penginterpretasian terhadap rangsangan yang diterima oleh individu sehingga merupakan sesuatu yang berarti (Walgito, 2008).

\section{KESIMPULAN}

Berdasarkan hasil penelitian maka dapat disimpulkan bahwa terdapat hubungan positif antara pengetahuan pengetahuan lingkungan hidup dengan kesadaran lingkungan pada siswa SMA Adiwiyata. Hal tersebut berarti jika skor pengetahuan lingkungan hidup tinggi, maka skor kesadaran lingkungan juga tinggi.

\section{SARAN}

Berdasarkan kesimpulan, maka perlu dipertimbangkan untuk penelitian selanjutnya adalah mencari faktor yang berkontribusi lebih besar terhadap kesadaran lingkungan. Selain itu, perlu memaksimalkan keterlibatan siswa dalam program Adiwiyata.

\section{DAFTAR PUSTAKA}

Azrai, E. P., Sigit, D. V., \& Puji, M. (2017). The Correlation Between Environmental Awareness and Students Participation in Go Green School Activity at Adiwiyata's School. BIOSFER, 10(2), 7-11.

Bowosantoso, J. T. (2015). Green School in the Perspective of Secondary School Students in Semarang, Central Java. IOSR Journal of Research \& Method in Education, 5(6), 34-42.

BPS [Badan Pusat Statistik]. 2017. Statistik Lingkungan Hidup Indonesia. Jakarta: Badan Pusat Statistik Indonesia.

Coyle, K.J.D. (2004). Understanding Environmental Literacy in America: and Making it a Reality. Washington DC: National Environmental Education \& Training Foundation.

Creech, H., McDonald, C., \& Kahlke, P. M. H. (2009). Measuring Knowledge, Attitudes and Behaviors Towards Sustainable Development: Two Exploratory Studies. Winnipeg CA: International Institute for Sustainable Development.

Darsita, Y., Saam, Z., Amin, B., \& Siregar, Y.I. (2015). Kesadaran Lingkungan Siswa Sekolah Adiwiyata. Dinamika Lingkungan Indonesia, 2(1), 61-64.

Heryanti, E., Matondang, M. N., \& Wati, D. A. (2016). The Correlation Between Student's Participation in Scouting Extracurricular and the Attitude of Environmental Awareness. BIOSFER, 9(2), 54-59.

Izzaty, A. M. (2014). The Effect of Students' Knowledge about Environmental Pollution (High Knowledge Vs Low Knowledge) to 
Critical Thinking. BIOSFER, VII(2), $1-3$.

Kementerian Lingkungan Hidup dan Kehutanan. (2017). Indeks Kualitas Lingkungan Hidup Indonesia 2016. Jakarta: Kementerian Lingkungan Hidup dan Kehutanan.

Kementerian Lingkungan Hidup. (2012). Panduan Adiwiyata : Wujudkan Sekolah Peduli dan Berbudaya Lingkungan. Jakarta: KLH.

Krech., dan Crutfield. (2000). The Psycology of Adolesence. New York: Hogton Miflin Company.

Kukreti, B. R., dan Gihar, S. (2004). Effect of Video Intervention Strategy on the Environmental Attitude of Secondary Students. Psycholingua, 34(1), 17-22.

Maryono. (2015). The Implementation of the Environmental Education at Adiwiyata Schools in Pacitan Regency. Journal of Education and Practice, 6(17), 31-43.

Rahman, N.A. (2016). Knowledge, Internal, and Environmental Factors on Environmental are Behaviour among Aboriginal Students in Malaysia. Journal Environ. Sci. Educ, 11(12), 5349-5366.

Sarker, R., Yeasmin, M., Rahman M.A., Islam, M.A. (2018). People's Perception and Awareness on Air Pollution in Rural and Urban Areas of Mymensingh Sadar upazila. Progressive Agriculture, 29(1), 2232.

Shobeiri, S. M., Omidvar, B., \& Prahallada, N. N. (2007). A Comperative Study of Environmental Awareness among Secondary School Students in Iran and India. International Journal of Environmental Research, 1(1), 2834.
Neolaka, Amos. (2008). Kesadaran Lingkungan. Jakarta: Rineka Cipta.

Notoatmodjo, S. (2007). Pendidikan dan Perilaku Kesehatan. Jakarta: Rineka Cipta.

Omoogun, A. C., \& Odok A., O. (2013). Influence of Gender and Environmental Awareness on Attitude of People towards Forest Conservation in Ekuri Communities. Journal of Public Administration and Governance, 3(2), 219-225.

Pe'er, S., Goldman, D., \& Yavetz, B. (2007). Environmental Literacy in Teacher Training: Attitudes, Knowledge, and Environmental behaviour of Beginning Students. Journal of Environmental Education, 39(1), 45-59.

Rahmahdini, R., Vivanti, D. S., \& Heryanti, E. (2014). The Effect of different Counseling Method toward Housewives' Knowledge about Processing of the Household Waste. BIOSFER, VII(2), 22-26. Siregar, Evelin dan Hartini, Nara. (2010). Teori Belajar dan Pembelajaran. Jakarta: Ghalia Indonesia.

Spinola, H. (2015). Environmental Literacy Comparison between Students Taught in Eco-schools and Ordinary Schools in The Madeira Island Region of Portugal. Science Education International, 26(3), 392413.

Vivanti, D. S., Ernawati, \& Qibtiah, M (2017). Hubungan Pengetahuan Lingkungan Hidup dengan Kemampuan Pemecahan Masalah Pencemaran Lingkungan pada Siswa SMAN 6 Tanggerang. BIOSFER, 10(2), 1-6.

Walgito, B. (2008). Psikologi Kelompok. Yogyakarta: CV Andi Offset.

Wihardjo, S. D., Hartati, S., Nurani, Y., \& Sujarwanta, A. (2017). The Effects 
of Green Schooling Knowledge Level and Intensity of Parental Guidance on the Environmental Awareness of The Early Age Student. Educational Research and Reviews, 12(5), 251-257.
Ziadat, A H. (2010). Major Factors Contributing to Environmental Awareness among People in a Third World Country/Jordan. Environment, Development and Sustainability, 12(1), 135-145. 